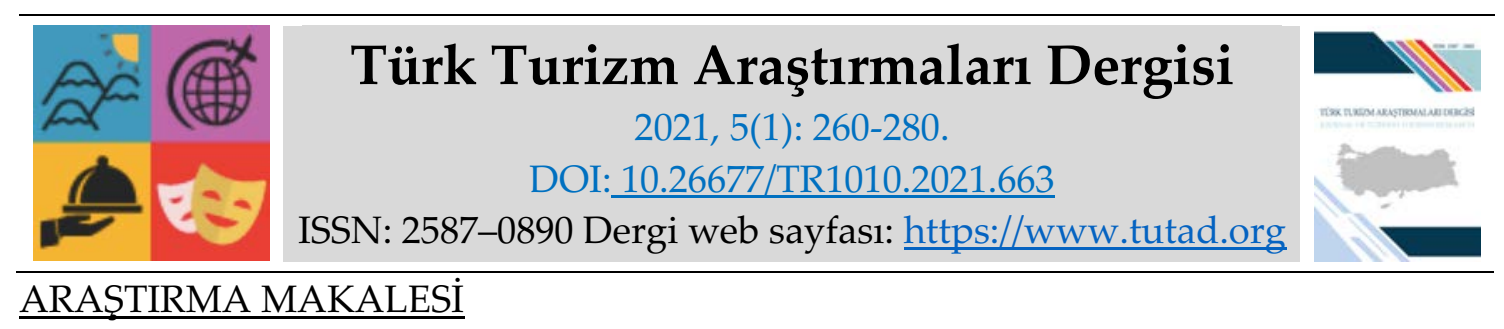

\title{
Koronavirüs (Covid-19) Sürecinde İç Turizmin Talepleri ve Turizm İşletmeleri Yöneticilerinin İç Turizme Yönelik Bakış Açılarının İncelenmesi*
}

Dr. Buket BULUK EŞiTTİ, Çanakkale Onsekiz Mart Üniversitesi, Turizm Fakültesi, Çanakkale, eposta: bulukbuket@comu.edu.tr

ORCID: https://orcid.org/0000-0001-5646-6166

\section{Öz}

Bu çalışmada, Covid-19 sürecinde Türkiye iç pazarının turizme yönelik talepleri ve turizm işletmeleri yöneticilerinin Covid-19 süreci ve sonrasına ilişkin iç pazara ve turizme yönelik bakış açıları tespit edilmeye çalışılmıştır. Çalışmanın verileri 15 Mart-01 Mayıs 2020 tarihleri arasında 650 yerli katılımcıdan ve Antalya ve Bodrum'da yer alan 20 turizm işletmesi yöneticisinden çevrimiçi olarak toplanmıştır. Araştırmanın öne çıkan bulgularına bakıldığında "Tüm seyahat kısıtlamalarının 15 Haziran'da kaldırıldığını varsayarsak ne kadar kısa sürede uçuş içeren bir yurt içi seyahate çıardınız?" sorusuna 650 katılımcının \%31,5 oranındaki kayda değer bir bölümünün "hemen" tatile çımaya hazır olduğu görülmüştür. Bu kapsamda çalışmada, iç pazarın turizm talebi göz önüne alınarak turizm yöneticilerinin iç pazara gereken önemi vermesi ve fiyatların iç pazarın yararlanabileceği şekilde revize edilmesi gerektiği önerilmiştir. Öte yandan turizm işletmeleri yöneticilerinin kriz ortamı geçince de otel fiyatlarının hemen arttırılmasının doğru olmadığını ve iç pazara gereken değerin verilmesi gerektiğini belirttikleri görülmüştür. Elde edilen sonuçların, 2020 yılı itibariyle önümüzdeki birkaç sezonunu Covid-19 gölgesinde geçireceği öngörülen turizm sektörü için Türkiye'deki turizm uygulayıcılarına yol göstereceği düşünülmektedir.

* Bu çalışma, 15-17 Ekim 2020 tarihlerinde Çanakkale Onsekiz Mart Üniversitesi ve Van Yüzüncü Yıl Üniversitesi'nin iş birliğiyle çevrimiçi (online) olarak düzenlenen IV. Uluslararası Batı Asya Turizm Araştırmaları Kongresi (IV. International West Asia Congress of Tourism Research)-IWACT'da sunulan bildirinin geliştirilmiş halidir.

Anahtar Kelimeler: İç Pazar, Koronavirüs (Covid-19), Turizm İşletmeleri Yöneticileri, Turizm Talebi, Türkiye.

Makale Gönderme Tarihi: 05.11.2020

Makale Kabul Tarihi: 02.03.2021

Önerilen Atıf:

Buluk Eşitti, B. (2021). Koronavirüs (Covid-19) Sürecinde İç Turizmin Talepleri ve Turizm İşletmeleri Yöneticilerinin İç Turizme Yönelik Bakış Açılarının İncelenmesi, Türk Turizm Araştırmaları Dergisi, 5(1): 260-280.

(c) 2021 Türk Turizm Araştırmaları Dergisi. 


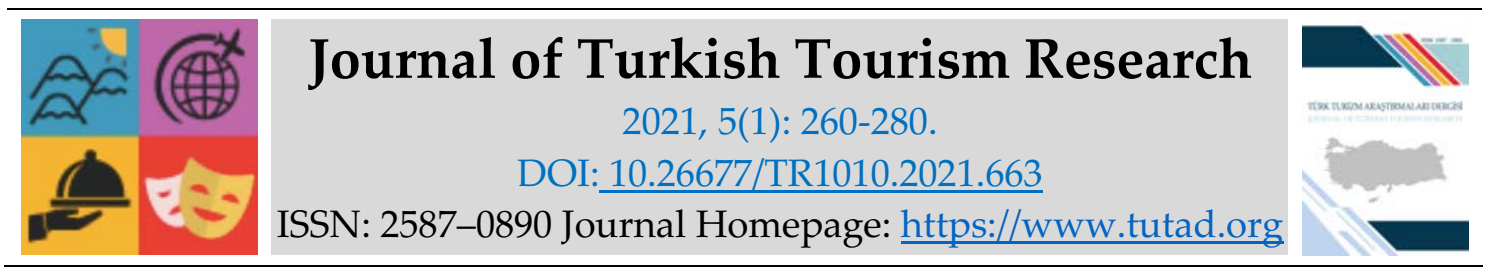

\title{
RESEARCH PAPER
}

\section{Investigation of Domestic Tourism Demands and Tourism Businesses Managers' Perspectives on Domestic Tourism in the Coronavirus (Covid-19) Process}

Dr. Buket BULUK EŞITTTI, Çanakkale Onsekiz Mart University, Faculty of Tourism, Çanakkale, e-mail: bulukbuket@comu.edu.tr ORCID: https://orcid.org/0000-0001-5646-6166

\begin{abstract}
In this study, the demand of tourism of Turkey's domestic market and perspectives of tourism businesses managers for the domestic market and tourism was tried to be determined in the process and after of Covid-19. The data were collected from 650 participants from Turkey and 20 tourism businesses managers in Antalya and Bodrum between 15 March-01 May 2020 as online. Considering the prominent findings of the study, it was observed that $31,5 \%$ of 650 participants were ready to go on vacation immediately as response to the question of "Assuming that all travel restrictions were lifted on June 15, how soon would you take a domestic trip with flights?". With this result in the study, it was suggested that tourism managers should give the necessary importance to the domestic tourism market by considering the demand and the prices should be revised in a way that the domestic market can benefit. On the other hand, it was observed that the managers of the tourism businesses stated that it was not right to increase the prices immediately after the crisis passed and that the necessary value should be given to the domestic market. The obtained results are considered to guide tourism practitioners in Turkey for the next few tourism seasons which are predicted to pass in the shadow of Covid-19 as of 2020.
\end{abstract}

Keywords: Coronavirus (Covid-19), Domestic Market, Tourism Businesses Managers, Tourism Demand, Turkey.

Received: 05.11.2020

Accepted: 02.03.2021

\section{Suggested Citation:}

Buluk Eşitti, B. (2021). Investigation of Domestic Tourism Demands and Tourism Businesses Managers' Perspectives on Domestic Tourism in the Coronavirus (Covid-19) Process, Journal of Turkish Tourism Research, 5(1): 260-280.

(C) 2021 Türk Turizm Araştırmaları Dergisi. 


\section{Gíriş}

İlk defa Çin Wuhan'da, 2019 yılının aralık ayında görülmesi ve Wuhan'daki yetkililerce tanımlanması nedeniyle "Wuhan Koronavirüsü" olarak da bilinen koronavirüs (Wu vd., 2020), solunum yolları enfeksiyonuna yol açan bulaşıcı bir virüstür (Schwartz ve Graham, 2020). Evcil ve yabani hayvanlar arasında yaygın olan koronavirüsün damlacık ve temas yoluyla bulaştığ 1 bilinmektedir (Kiros vd., 2020). İlk defa 2019 yılı içerisinde tanımlanmış olması, koronavirüsün global anlamda kabul gören adının "Covid-19" olmasına yol açmıştır. Oluşturduğu küresel salgın durumundan ötürü Dünya Sağllk Örgütü (WHO) Covid-19'u "pandemi" ilan etmiştir. Dünya Sağlık Örgütü (WHO) (2020)'ye göre, 6 Aralık 2020 tarihi itibariyle dünya çapında Covid19 ile enfekte olan insan sayısının 65,651,683; ölü sayısının 1,519,193 ve yeni vaka sayısının ise 393,255 olduğu görülmektedir.

Dünya Turizm Örgütü (UNWTO) (2020), Covid-19 pandemisinin global bağlamda bir turizm krizinin yaşanmasına yol açtığını vurgulayarak Covid-19 salgını nedeniyle uluslararası turizmin \%20-30 düşebileceğini, bu oranda gerçekleşecek bir düşüşün uluslararası turizm endüstrisinde 2020 yılı için 300-450 milyar dolarlık kayba yol açabileceğini, bu rakamın ise 2019 yılındaki 1,5 trilyon dolar olan turizm gelirlerinin ortalama $1 / 3$ 'ünü oluşturduğunu belirtmiştir. Ülkelerin birçoğu, 2020 yaz sezonunun açllış tarihine yönelik birtakım öngörülerde bulunsalar da birçok ülkenin uluslararası seyahat kısıtlama ve yasaklarının devam ettiği görülmektedir (SOCEMIE, 2020). Türkiye'de ise yıllık 35 milyar dolar olan turizm gelirlerinin 2020 yılında ciddi bir düşüş göstereceği öngörülmektedir. Türkiye'nin 2020 mart ayı otel doluluk oranlarının, 2019'un aynı dönemine kıyasla \%50 azalarak \%28,6 olarak kaydedildiği belirtilmiştir (Ersöz ve Öztürk, 2020).

Turizm uzmanlarının, 2020 Türkiye turizmindeki canlanmanın iç pazar ile başlayacağını öngördükleri görülmektedir (Karayal ve Küçükyılmaz, 2020). Erdoğan (1995:464) tarafından iç turizm pazarı, "iç turizm ülke sakinlerinin, kendi ülkeleri içindeki turist aktiviteleri" şeklinde tanımlanmıştır. Döviz kazandırıcı etkisinin olmaması ve devletin teşvik etmemesi gibi sebeplerle Türkiye coğrafyasında iç turizmin yeteri kadar gelişmediği bilinmektedir (Gökdeniz vd., 2009). Oysa iç turizm pazarı, ülkeler bazında turizm sektörüne olumlu katkı sağlamakta ve dış, turizm pazarının desteklenmesi konusunda bir "yardımcı güç" olarak kabul görmektedir (Güzel, 2011). Türkiye ise iç turizm pazarının önemini yeteri kadar anlamamış; turizm işletmeleri tarafından iç turizm pazarı çoğunlukla ikincil bir pazar olarak değerlendirilmiştir (Tanrıverdi ve Oktay, 2002). Türkiye'de dış turizm pazarı nedeniyle iç turizm pazarı genellikle göz ardı edilmiştir. Buna rağmen ani gelişen durumlar karşısında iç pazar, turizm işletmeleri tarafından "kurtarıcı" olarak kabul görmüş̧ür. Bilhassa kriz dönemlerinde, iç pazarın "kurtuluş aktörü" olarak işlev gördüğü dikkat çekmektedir. 1991 yılındaki Körfez Savaşı krizinde iç turizm pazarı, dış turizm pazarını ilk sıraya koyan turizm işletmeleri tarafından "çözüm" olarak kullanılmış ve bu kriz iç turizm pazarı aracılığıyla aşılmıştır. 2006 yılında gerçekleşen Avrupa kupası, kuş gribi gibi olumsuz birtakım olaylar da dış turizm hareketlerinin azalmasına yol açmış ve "kurtarıcı" yine iç turizm pazarı olmuştur. Yine, 2016 yılında Rusya ile yaşanan uçak krizinin ardından 2016 turizm sezonunun kurtarıcısı iç turizm pazarı olmuştur (Kilit, 2020). İç pazar, iç turizm pazarı gibi kavramlarla da ifade edilen iç turizm hareketleri, dış turizm hareketleri ile kıyaslandığında iç pazarın kriz ve olumsuz koşullardan etkilenmedikleri veya çok daha az etkilendikleri, aksine turizm işletmelerinin "sadık turizm pazarı" oldukları ifade edilmiştir (Gursoy ve Gavcar, 2003).

Yukarıdakilerden hareketle bu çalışmada, Covid-19 sürecinde Türkiye iç pazarının turizme yönelik talepleri ölçülmeye ve turizm işletmeleri yöneticilerinin Covid-19 süreci ve sonrasına ilişkin iç pazara ve turizme yönelik bakış açıları tespit edilmeye çalışılmıştır. Elde edilen 
sonuçların, tüm dünyada Covid-19 gölgesinde açılacak olan 2020 yılı itibariyle önümüzdeki birkaç sezonunu Covid-19 gölgesinde geçireceği öngörülen turizm sektörü için Türkiye'deki turizm pazarlamacılarına ve uygulayıcılarına katkı sağlayacağı ve yol göstereceği düşünülmektedir.

\section{KORONAVİRÜS (COVID-19) SÜRECINNDE DÜNYADA ve TÜRKİYE'DE TURİZM}

Covid-19 pandemi sürecinin doğrudan ve büyük oranda etkilediği sektörlerin ilk sırasında şüphesiz turizm sektörü gelmektedir (Önal, 2020). Dünya Turizm Örgütü (UNWTO), 25 Mart 2020 tarihinde yapmış olduğu öngörüsünde bu etkinin 290-440 milyon turistik seyahate olumsuz yansıyacağını, turizm gelirlerinde 300-450 milyar dolar arasında kayıp olacağını ve 1,5 trilyon dolar olan turizm ihracat gelirlerinin ise 1/3 oranında azalacağını belirtmiş̧tir. Covid-19 pandemisi sürecinde ülkelere bakıldığında, 2020'nin etkisinin Fransa için -\%40 ile 38 milyon turist azalışı; İspanya için -\%42 ile 34 milyon turist azalışı; İtalya için -\%49 ile 31 milyon turist azalışı; Türkiye için -\%34 ile 18 milyon turist azalışı; Almanya için -\%39 ile 15 milyon turist azalışı; Yunanistan için -\%36 ile 11 milyon turist azalışı olacağı öngörülmektedir (Bahar, 2020). Dünya Turizm ve Seyahat Konseyi (WTTC) (2020)'nin bütün ülke hükümetlerine gerçekleştirdiği çağrısında Covid-19 pandemisi esnasında ve sonrasına yönelik adımlar için ülkelere mümkün olduğu kadar vizeleri kaldırmalarını, seyahat vergisinden vazgeçmelerini ve teşvikleri devreye sokmalarını önermiştir. Ayrıca, Covid-19 salgınının kontrol altına alınmaya başlamasıyla beraber de kişilerin seyahatlerini iptal etmemelerinin veya ertelememelerinin önünün açılmasını sağlayacak uygulamaların geliştirilmesi ve teşvik edilmesine yönelik çağrıda bulunmuştur.

Ülkelerin, Covid-19 pandemisi süresinde 2020 tatil sezonunun ne zaman açılacağına yönelik birtakım öngörülerde bulunmalarına rağmen (www.turizmyatirimdergisi.com.tr), çoğu ülkenin uluslararası seyahat kısıtlamalarının devam ettiği görülmektedir. Türkiye için ise yıllık 35 milyar dolar olan turizm gelirlerinin 2020 yılı için oldukça yüksek seviyelerde düşüş göstereceği değerlendirilmektedir (Ersöz ve Öztürk, 2020). Dünya Seyahat ve Turizm Konseyi (2020)'nin verileri doğrultusunda, dünya çapındaki turizm gelirlerinin milli ekonomiler üzerindeki katkısının en fazla olduğu ülkeler olan Tayland (\%22), Filipinler (\%21), Meksika (\%16,1), İspanya $(\% 14,9)$ ve İtalya (\%13)'ün Covid-19 krizinin en fazla etkilediği ülkeler arasında yer aldığ1; turizmin ülke ekonomisine katkısının \%11,6 olduğu Türkiye'nin ise Covid-19 salgınından etkilenen altıncı ülke olduğu belirtilmiştir. Turizm istatistiklerinin ülke ekonomilerini en olumsuz etkilediği diğer ülkelerin ise sırasıyla Çin (\%11), Avustralya (\%11), Almanya (\%10,7), İngiltere $(\% 10,5)$ ve Arjantin $(\% 10,2)$ olduğu belirtilmiştir. Dünya genelinde ise turizm gelirleri en fazla olan Bahamalar, Jamaika, Makao, Gürcistan, Virgin Adaları, İzlanda, Malta, Maldivler ve Kamboçya gibi destinasyonların Covid-19 pandemisinin yol açtı̆̆ seyahate yönelik yasaklamalar nedeniyle gelirlerinin oldukça fazla düştügü ifade edilmiştir.

Türkiye Otelciler Birliği (TÜROB) (2020)'nin yaptı̆̆ı açıklama doğrultusunda, Covid-19 pandemisi küresel anlamda turizm faaliyetlerini bitme aşamasına getirmiş, pandemi nedeniyle küresel çaptaki konaklama işletmelerinin doluluk seviyelerinde de öngörüldüğü şekilde büyük düşüşler yaşanmıştır. Mart 2020'de Avrupa ülkelerinde doluluk oranları kapsamında en büyük düşüşü \%90,8 gibi büyük bir oranla İtalya yaşamıştır. Dünya geneli bazında en yüksek doluluk oranının \%48,5 ile Sydney olduğu; Los Angeles şehrinde bu oranın \%42,5 ve New York şehrinde ise bu oranın \%34,5 olarak gerçekleştiği tespit edilmiştir. Çin'in başkenti Pekin'in mart ayındaki doluluk oranı ise \%16,4 olmuştur (Congar, 2020). Mart 2020 kapsamında doluluk oranları açısından ülkeler baz alındığında en yüksek doluluğun \%36,5 ile İngiltere'ye ait olduğu belirtilmiştir. Türkiye destinasyonunun Mart 2020'deki otel doluluk oranları ise 2019 yılının aynı 
dönemine kıyasla \%55,2 azalarak, \%28,6 olarak kaydedilmiştir. 2019 yılı Mart ayında bu oran $\% 63,8$ olarak gerçekleşmişti. İstanbul'un Mart 2019'da \%72,1 olan doluluk oranı, Mart 2020'de $\% 59,8$ azalarak \%29 olarak ölçülmüştür (Ersöz ve Öztürk, 2020). Türkiye Otelciler Birliği (TÜROB) (2020)'nin verilerine göre, Türkiye'nin yaz mevsiminde en çok turist çeken şehri olan Antalya'da Mart 2020 otel dolulukları bir önceki yılın ayn dönemine göre \%49,4 azalarak \%29 olmuştur. Antalya'da ortalama günlük satılan oda bedeli 39 Euro ile Mart 2019'a göre \%18 gerilemiştir. Toplam oda sayısı üzerinden odabaşı elde edilen gelirlerde ise geçen yıla oranla \%58,5 düşüş yaşanmış ve ortalama günlük satılan oda bedeli 11,3 Euro olarak ölçülmüştür.

Tüm dünyayı etkisi altına alan Covid-19'un ulaşımdan eğitime, emlaktan alışverişe etkilemediği sektörün neredeyse yok denecek kadar az olduğu görülmektedir (Şahin, 2020). Uzmanlar tarafından bu durumdan olumsuz etkilenen sektörlerin çoğunlukta olduğu ve bunların başında da turizm sektörünün geldiği belirtilmektedir (Balcı ve Çetin, 2020). Bu süreçte birçok ülke sınırlarını kapatırken, vatandaşları için de sokağa çıkma yasağı uygulamaktadır. Bu nedenle turizm tam anlamıla durma noktasına gelmiştir (Kadüker, 2020). Uzmanlara göre salgın, turizm sektörü için 2020'yi kayıp yıl haline getirebilir. Uzmanlar tarafından şartların normalleşmesi durumunda, 2020 yaz sezonu sonlarında Almanya pazarından Türkiye'ye az da olsa turizm hareketlerinin olabileceği, sonbahar döneminde salgının yeniden artışa geçmemesi halinde turizm istatistiklerinin toparlanacağı ifade edilmektedir. Bu noktada turizm uzmanlarının, 2020 Türkiye turizmindeki canlanmanın iç pazar ile başlayacağını belirttikleri görülmektedir (Karayal ve Küçükyılmaz, 2020). Turizmciler de benzer bir tabloyu öngörürken, yurt içinde hareketin daha hızlı başlayabileceğini, yurt dışında ise yaz ayları ortasına kadar belli bir hareket oluşmayacağını belirmektedirler. Dünyadaki normalleşme ve salgının kontrol altına alınmasıyla birlikte turizmde tercih edilecek ilk ülkenin Türkiye olacağına vurgu yapan turizmcilerin, 2021 yılı için de pazarlamanın aynı dönemde başlatılmasını önerdikleri dikkat çekmektedir (Bağlıkaya, 2020).

Öte yandan Kültür ve Turizm Bakanlığı, 2020 yılı yaz sezonundan itibaren geçerli olacak “Sağlıklı Turizm Sertifikasyonu" programını başlatmıştır (Guzel, 2020). Daha önce "Korona Sertifikası" olarak da duyurulan "Sağlıklı Turizm Sertifikasyon" programı, Kültür ve Turizm Bakanlığg'nın önderliğinde Sağlık Bakanlığı, Ulaştırma Bakanlığı, İçişleri Bakanlığı ve Dışişleri Bakanlığının katkılarıyla beraber diğer sektörlerin paydaşlarının iş birlikleriyle hazırlanmıştır. "Sağlıklı Turizm Sertifikasyonu", tatillerini Türkiye'de geçirecek olan yerli ve yabancı turistlerin ulaşım ve konaklamalarından çalışan personelin ve turistlerin sağlık durumlarına kadar alınan bütün önlemleri ifade etmektedir. Uluslararası sertifikasyon kuruluşlarının vereceği Sağlıklı Turizm Sertifikasyonu; ulaşım araçlarında, konaklama ve yiyecek içecek tesislerinde daha önceden belirlenmiş üst düzey sağlık ve hijyen şartlarının sağlandığını gösteren belgelerin tümüdür (Türkiye Turizm Tanıtım ve Geliştirme Ajansı, 2020). Covid-19 pandemisi sürecinde edinilmesi zorunlu kılınmamasına rağmen T.C. Kültür ve Turizm Bakanlığı'nın alınması için teşvik ettiği Sağlıklı Turizm Sertifikasyonu, 4 Mayıs 2020 tarihi itibariyle tamamlanmıştır. Kültür ve Turizm Bakanlığı tarafından hazırlanan ve 129 maddeden oluşan "Sağlıklı Turizm Sertifikasyonu" programı listesinde, mutfak prosedürlerinin standart hijyen prosedürleri ile sinırlı kaldığ 1 görülürken, personele Milli Eğitim Bakanlı̆̆ı'nın onayladığı hijyen sertifikasının verilmesi, misafirlere verilmesi gereken koruyucu kıyafetlerin konaklama tesislerinde bulundurulması ve SPA, hamam, fitness salonları ve açık büfelerin faaliyet gösterme düzenlemeleri gibi konuların Sağlıklı Turizm Sertifikasyonunun öne çıan noktaları olduğu görülmektedir. T.C. Kültür ve Turizm Bakanı Ersoy (2020), seyahat acentalarının tamamının sertifikasyon sistemi konusunda bilgilendirildiklerini ve yerli ve yabancı turistlerin "Sağlıklı Turizm Sertifikası"'na sahip konaklama tesislerine öncelik vereceklerini ifade etmiştir. 
Son olarak Yavuz (2020), dünyadaki en önemli 13 tatil destinasyonunun (İtalya, İsviçre, Fransa, Türkiye, Danimarka, Yunanistan, Hırvatistan, Birleşik Arap Emirlikleri, Slovakya, Çekya, İspanya, İsrail ve Avusturya) Covid-19 krizini ve bu ülkeler açısından önemli bir gelir kaynağ 1 konumundaki turizm sektörüne yönelik çözüm önerilerini özetlediği yazısında, bu ülkelerin yaklaşık 400 milyon turist aldığını ve her biri için turizmin çok önemli olduğunu belirttiği görülmektedir. Yavuz (2020) ayrıca, 2020 yılı yaz sezonunda insanların çoğunun kendi ülkelerinde tatil yapacaklarını, ancak ne taşıma kapasitesinin ne de hava şartlarının bu yoğunluğu kaldıramayacağı sebebiyle yaz ortasında rotanın yurt dışına döneceğini belirtmiştir. Bunun nedenini ise biraz da ekonomik olarak yurt dışının daha cazip gelmesiyle ilişkilendirmiştir. Yavuz (2020) son olarak, birçok ülkenin 2020 yılı yazı için kendini dışarıya kapattığını ve bu sezonu gözden çıkarmış durumda olduklarını ifade ederken, bazılarının ise çok istemekle birlikte çözümsüzlükten ya da yaratıcılık eksikliğinden işi akışına bırakmış durumda olduklarını belirtmiştir.

Özetle, Covid-19'un ve etkilerinin ne zaman biteceğine yönelik net bir tarih olmasa da dünya ülkeleri içinde özellikle istek ve çözümleri ile açık ara öne çıkan ülkenin Türkiye olduğu anlaşılmaktadır. Ayrıca, Türkiye bu konudaki projelerine ek olarak büyük, geniş, ferah otellerini ve sahillerini de eklerse Türkiye'nin bir adım daha öne çıkabileceği ve 2020 yazında uluslararası turizmin gerçekleşeceği nadir ülkelerden birisi olabileceği söylenebilir.

\section{YÖNTEM}

Bu çalışmada, Covid-19 sürecinde Türkiye iç pazarının turizme yönelik talepleri ölçülmeye ve turizm işletmeleri yöneticilerinin Covid-19 süreci ve sonrasına ilişkin iç pazara ve turizme yönelik bakış açıları tespit edilmeye çalışılmıştır. Çalışmanın verileri 15 Mart-01 Mayıs 2020 tarihleri arasında toplanmıştır. Karma yönteminin kullanıldığı araştırmada veriler hem nitel hem de nicel veri toplama araçları kullanılarak toplanmıştır. İç pazarın turizm taleplerini ölçmeye yönelik verilerin elde edilmesinde çevrimiçi anket yönteminden yararlanılmıştır. Magma Global tarafından 1955 kişi üzerinde Avrupa için yapılan "Travel Post Covid-19" araştırmasında kullanılan çevrimiçi anket formu ile birlikte Müstakil Sanayici ve İş Adamları Derneği (MÜSİAD) tarafından Türkiye genelinde 822 kişi üzerinde yapılan "Covid-19 Sürecinde Türkiye'de İç Turizm Talebi: Mevcut Durum ve Beklentiler" araştırmasında kullanılan soru formundan da yararlanılarak alanında uzman beş farklı akademisyenin görüssleri doğrultusunda Türkçeye de gerekli uyarlamaların yapılmasının ardından Türkiye'den 1000 katılımcıya gönderilmiş ve eksiksiz bir şekilde geri dönüş yapan 650 adet anket formu değerlendirmeye alınmıştır. Burada örneklem seçiminde "kolayda örnekleme" kullanılmıştır. Kolayda örnekleme yöntemi, "ana kütle içerisinden seçilecek örnek kesimin araştırmacının yargılarınca belirlendiği tesadüfî̀ olmayan örnekleme yöntemidir" (Malhotra, 2004:321). Kolayda örnekleme yönteminde verilerin, ana kütleden en basit, çabuk ve ekonomik bir biçimde toplandığı belirtilmektedir. Ana kütlenin sayısının net bir şekilde bilinemediği durumlarda değerlendirilmesi gereken örneklem sayısının minimum 384 (Altunışık vd., 2007) olması nedeniyle, 650 adet verinin söz konusu rakamı fazlasıyla tamamladığı söylenebilir.

Turizm işletmeleri yöneticilerinin örneklem seçiminde ise "amaçlı örneklem" yönteminden yararlanılmıştır. Amaçlı örneklemde araştırmacı/araştırmacılar, çalışmaya dâhil olacak katılımcıları kendileri belirlerler (Şimşek, 2012). Örnek vermek gerekirse, katılımcılar çalışılan konuya yönelik sahip oldukları deneyim veya bilgiye göre seçilebilirler. Bu anlamda çalışmada Türkiye turizmi yaz sezonunun en yoğun destinasyonları olan Antalya ve Bodrum destinasyonlarında, Antalya'da 20 adet ve Bodrum'da 20 adet olmak üzere toplamda 40 adet her 
şey dahil turizm işletmesi belirlenerek bu işletmelerle iletişime geçilmiş, konunun kapsamı, amacı ve sorular paylaşılarak görüşme formları işletmelerin mail adreslerine gönderilmiştir. İşletmelerden, gönderilen görüşme formlarını işletme yöneticilerine ulaştırmaları istenmiş ve yarı yapılandırılmış sorulardan oluşan görüşme formuna katılmak isteyen yöneticilerin formun üzerinde yer alan mail adresine cevapladıkları formları göndermeleri istenmiştir. Davete dönüş yapan 25 görüşme formundan 5 adedinin eksik yanttlar içermesi nedeniyle 5 adet görüşme formu elenmiş, geriye kalan ve eksiksiz olduğu görülen 20 adet görüşme formunun tamamı çalışmaya dâhil edilmiştir. Dolayısıyla yarı yapılandırılmış görüşme formuna geri dönüş, oranının \%50 olduğu belirtilebilir.

\section{Verilerin Analizi}

Çalışma kapsamında katılımcıların özellikleri ve turizm taleplerine yönelik sorulara verdikleri cevaplar frekans analizine tabi tutulmuştur. Turizm işletmeleri yöneticileriyle gerçekleştirilen görüşmelerden elde edilen veriler kapsamında ise çalışmanın kuramsal yapısı ve katılımcılardan elde edilen görüşmelerden verilerin analizi için bir çerçeve oluşturulmuştur. Bu doğrultuda veriler iki ana başlık altında düzenlenmiştir. Bu başlıklar;

- Türkiye'de Koronavirüs (Covid-19) salgını öncesinde iç pazara ilişkin değerlendirmeler,

- Türkiye'de Koronavirüs (Covid-19) salgını süreci ve sonrası için iç pazara ve turizme ilişkin değerlendirmeler,

Nitel araştırmalarda geçerlik ve güvenirlik; "inandırıcıllk", "aktarılabilirlik", "tutarlılık" ve "doğrulanabilirlik" çerçevesinde değerlendirildiğinde "daha anlamlı" ve "kabul edilebilir" sonuçlar ortaya konulabilmektedir (Büyüköztürk vd., 2017). Bu kapsamda tanımlanmış verilere yönelik bulguların betimlenerek açıklanması gerekmektedir. Betimsel geçerliğin sağlanabilmesi amacıyla görüşmeler özgün halleriyle gruplandırmalar yapılarak sunulmaktadır.

\section{Katılımcıların Tanımlayıcı Özellikleri}

Araştırma kapsamında yer alan katılımcılara yönelik betimsel analiz sonuçları ve tablolar aşağıda verilmiştir. Tablo 1'e göre, katılımciların \%46,9'u "kadın" katılımcılardan, \%53,1'i ise "erkek" katılımcılardan oluşmaktadır. Katılımcılar yaş dağılımlarına göre incelendiğinde ise, "26-44" $(\% 42,4)$ ve "45-64" $(\% 28,9)$ yaş grubundaki katılımciların çoğunluk olduğu görülmektedir. Buna ek olarak, "18-25" yaş grubunu oluşturan katılımcıların oranının \%11,7; "65 yaş ve üstü" katılımcıların yaş oranlarının ise $\% 17,0$ olduğu görülmektedir.

Katılımcıların eğitim durumları incelendiğinde ise, ilk sırada \%47,5 ile "lisans" mezunlarının yer aldığı görülmektedir. İkinci sırada \%27,9 ile "önlisans/MYO” mezunlarının, üçüncü sırada \%12,6 ile "lise ve altı" mezunlarının ve son olarak dördüncü sırada ise \%12,0 ile "lisansüstü" mezunlarının yer aldığı görülmektedir. Katılımcıların medeni durumlarına göre dağılımlarına bakıldığında ise, \%74,9'unun "evli"; \%25,1'inin ise "bekâr" olduğu görülmektedir.

Katılımcılar aylık gelir dağılımlarına göre incelendiklerinde, \%27,3 ile ilk sırada "3501-4500 TL" gelir grubunun yer aldığı görülmektedir. İkinci sırada \%25,2 ile "4501-5500 TL" gelir grubunun; üçüncü sırada \%17,6 ile "2325-3500 TL" gelir grubunun, dördüncü sırada \%12,5 ile "6501 TL ve üstü" gelir grubunun, beşinci sırada \%9,5 ile "5501-6500TL" gelir grubunun ve son olarak \%7,9 ile "2324TL ve altı" gelir grubunun yer aldığı görülmektedir. 
Tablo 1. Katılımcıların Tanımlayıcı Özellikleri (n: 650)

\begin{tabular}{|c|c|c|c|c|c|}
\hline & $\mathbf{N}$ & $\%$ & & $\mathbf{N}$ & $\%$ \\
\hline \multicolumn{6}{|l|}{ Cinsiyet } \\
\hline Kadın & 305 & 46,9 & Erkek & 345 & 53,1 \\
\hline \multicolumn{6}{|l|}{ Yaş } \\
\hline $18-25$ & 76 & 11,7 & $45-64$ & 188 & 28,9 \\
\hline $26-44$ & 276 & 42,4 & 65 ve üstü & 110 & 17,0 \\
\hline \multicolumn{6}{|l|}{ Eğitim Durumu } \\
\hline Lise ve alt1 & 82 & 12,6 & Lisans & 309 & 47,5 \\
\hline Önlisans/MYO & 181 & 27,9 & Lisansüstü & 78 & 12,0 \\
\hline \multicolumn{6}{|l|}{ Medeni Durum } \\
\hline$\overline{\text { Evli }}$ & 487 & 74,9 & Bekâr & 163 & 25,1 \\
\hline \multicolumn{6}{|l|}{ Aylık Gelir } \\
\hline 2324 TL ve altı & 51 & 7,9 & $4501-5500 \mathrm{TL}$ & 164 & 25,2 \\
\hline 2325-3500 TL & 114 & 17,6 & $5501-6500 \mathrm{TL}$ & 62 & 9,5 \\
\hline 3501-4500 TL & 178 & 27,3 & 6501 TL ve üstü & 81 & 12,5 \\
\hline \multicolumn{6}{|l|}{ Mesleki Durum } \\
\hline Çalışan & 457 & 70,3 & Öğrenci & 64 & 9,9 \\
\hline Emekli & 87 & 13,3 & İşsiz & 42 & 6,5 \\
\hline
\end{tabular}

Son olarak katılımclar mesleki durumlarına göre incelendiklerinde, "çalışan" katılımcıların ilk sırada \%70,3 ile büyük çoğunluğu oluşturdukları görülmektedir. Çalışan grubunu, \%13,3 ile "emekli" grubu takip ederken; üçüncü sırada \%9,9 ile "öğrenci" grubunun yer aldığ ve son olarak dördüncü sırada katılımcıların \%6,5'inin "işsiz" oldukları tespit edilmiştir.

Katılımcıların turizm taleplerine yönelik sorulara verdikleri cevaplar incelendiğinde (Tablo 2), katılımcıların kendilerine sorulan “Tüm seyahat kısıtlamalarının 15 Haziran'da kaldırıldığını varsayarsak, ne kadar kısa sürede uçuş içeren bir yurt içi seyahate çıkardınız?" sorusuna katılımcların \%31,5'inin "hemen", \%20,1'inin "15 Temmuz'da", \%16,7'sinin "15 Temmuz-15 Ağustos aralı̆̆ında", \%16,2'sinin "15 Ağustos itibariyle", \%15,5'inin ise "Aşı bulunduğunda" şeklinde cevap verdikleri görülmüş̧ür. İkinci olarak katılımcılara sorulan "Tüm seyahat kısıtlamalarının 15 Haziran'da kaldırıldığını varsayarsak, çıkacağınız ilk yurtiçi seyahatinizde hangi ulaşım aracından yararlanmayı düşünürsünüz?" sorusuna katılımcıların \%63,0'ının "Özel araç”, \%22,7'sinin “Diğer (tren, gemi vb.)”, \%8,0'ının “Otobüs”, \%6,3'ünün ise “Uçak” cevabını verdikleri tespit edilmiştir. Üçüncü olarak katılımcılara sorulan "Tüm seyahat kısıtlamalarının 15 Haziran'da kaldırıldığını varsayarsak, yurtiçi tatile çıkmayı düşünür müsünüz?" sorusuna katılımciların \%65,0'ının "Evet", \%24,1'inin "Kararsızım" ve \%10,9'unun "Hayır" yanıtını verdikleri saptanmıştır. Dördüncü olarak katılımcılara sorulan "Tüm seyahat kısıtlamalarının 15 Haziran'da kaldırıldığını varsayarsak, tatil planınız için bir seyahat acentasından yararlanmayı düşünür müsünüz?" sorusuna katılımciların \%56,5'inin "Kararsızım", \%29,7'sinin "Evet" ve \%13,8'inin "Hayır" cevabını verdikleri tespit edilmiştir. Beşinci olarak katılımcılara sorulan "2020 yaz sezonu bitmeden bir otelde tatil yapmayı planliyor musunuz?" sorusuna katılımciların \%39,4'ünün "Hayır", \%32,8'inin "Evet" ve \%27,8'inin ise "Kararsızım" cevabını verdikleri tespit edilmiştir. Altıncı soru olarak katılımcılara yöneltilen "2020 yaz sezonu bitmeden bir otelde tatil yapmayı planladığınızı varsayarsak, tatil yapmak için tercih edeceğiniz otel aşağıdakilerden hangisi olur?" sorusuna katılımcların \%33,9'unun "Apart/Pansiyon", \%32,6'sının "Butik otel", $\% 27,5$ 'inin "Her şey dahil otel" ve \%6,0'ının "Tatil köyü" yanıtını verdikleri saptanmıştır. Yedinci soru olan "2020 için otel rezervasyonu yaptırdınız mı?" sorusuna katılımcıların \%68,6'sının 
"Hayır, yaptırmadım", \%20,5'inin "Evet, tarihi gelince gideceğiz" ve \%10,9'unun "Yaptırdım, ama iptal ettirdim" cevabını verdikleri görülmüştür. Sekizinci soru olarak katılımcılara yöneltilen “Otellerin sertifikalarına ne derece güvenirsiniz?" sorusuna katılımcıların \%35,9'unun "Kararsızım", \%33,7'sinin “Kısmen güvenirim", \%22,3'ünün “Kesinlikle güvenirim” ve \%8,1'inin ise "Kesinlikle güvenmem" yanıtını verdikleri görülmüştür.

Tablo 2. Katılımciların Turizm Taleplerine Yönelik Sorulara Verdikleri Cevaplar (n:650)

1. Ne kadar kısa sürede uçuş içeren bir yurt içi seyahate çıkılacağı?

\begin{tabular}{|l|c|c|l|c|c|}
\hline & $\mathbf{N}$ & $\mathbf{\%}$ & & $\mathbf{N}$ & $\mathbf{\%}$ \\
\hline Hemen & 206 & 31,5 & 15 Temmuz-15 Ağustos & 108 & 16,7 \\
\hline Aşı bulunduğunda & 101 & 15,5 & 15 Ağustos itibariyle & 105 & 16,2 \\
\hline 15 Temmuz'da & 131 & 20,1 & & &
\end{tabular}

2. Çıkılacak ilk yurtiçi seyahatte hangi ulaşım aracından yararlanmanın düşünüldüğü?

\begin{tabular}{|l|c|c|l|c|c|}
\hline Özel araç & 409 & 63,0 & Uçak & 41 & 6,3 \\
\hline Otobüs & 52 & 8,0 & Diğer (Tren, gemi vb.) & 148 & 22,7 \\
\hline
\end{tabular}

3. Yurtiçi tatile çıkma düşüncesi?

\begin{tabular}{|l|c|c|l|c|c|}
\hline Evet & 423 & 65,0 & Kararsızım & 156 & 24,1 \\
\hline Hayır & 71 & 10,9 & & & \\
\hline 4. Tatil planı için bir seyahat acentasından yararlanma düşüncesi? & 367 & 56,5 \\
\hline Evet & 193 & 29,7 & Kararsızım & & \\
\hline Hayır & 90 & 13,8 & & 181 & 27,8 \\
\hline 5. 2020 yaz sezonu bitmeden bir otelde tatil yapma planı? & & & & \\
\hline Evet & 213 & 32,8 & Kararsızım & & \\
\hline Hayır & 256 & 39,4 & &
\end{tabular}

6. 2020 yaz sezonu bitmeden bir otelde tatil yapmanın planladığı varsayılırsa, tatil yapmak için tercih edilecek otel?

\begin{tabular}{|l|c|c|l|c|c|}
\hline Apart/Pansiyon & 220 & 33,9 & Her şey dahil otel & 179 & 27,5 \\
\hline Butik otel & 212 & 32,6 & Tatil köyü & 39 & 6,0 \\
\hline
\end{tabular}

7. 2020 için otel rezervasyonu yaptırma durumu?

\begin{tabular}{|l|c|c|l|c|c|}
\hline Yaptırdım, ama iptal ettirdim. & 71 & 10,9 & Hayır, yaptırmadım. & 446 & 68,6 \\
\hline Evet, tarihi gelince gideceğiz. & 133 & 20,5 & & & \\
\hline
\end{tabular}

8. Otellerin sertifikalarına güvenme durumu?

\begin{tabular}{|l|c|c|l|c|c|}
\hline Kesinlikle güvenirim & 145 & 22,3 & Kararsizım & 233 & 35,9 \\
\hline Kısmen güvenirim & 220 & 33,7 & Kesinlikle güvenmem & 52 & 8,1 \\
\hline
\end{tabular}

9. Gönül rahatlığıyla bir otelde tatil yapmak için salgının hangi ayda tamamen bitmesi gerektiği düşüncesi?

\begin{tabular}{|c|c|c|c|c|c|}
\hline Haziran & 183 & 28,1 & Ağustos & 128 & 19,7 \\
\hline Temmuz & 192 & 29,5 & Eylül & 147 & 22,7 \\
\hline \multicolumn{6}{|c|}{ 10. Avrupa'ya seyahat planının en erken düşünüldüğü dönem? } \\
\hline Kisıtlamalar kalkarsa hemen & 127 & 19,5 & Yeni yılda & 210 & 32,4 \\
\hline Aş1 bulunduktan sonra & 313 & 48,1 & & & \\
\hline \multicolumn{6}{|c|}{ 11. Asya'ya seyahat planının en erken düşünüldüğg̈u dönem? } \\
\hline Kisıtlamalar kalkarsa hemen & 66 & 10,1 & Yeni yılda & 113 & 17,4 \\
\hline Aşı bulunduktan sonra & 471 & 72,5 & & & \\
\hline
\end{tabular}

Dokuzuncu soru olarak katılımcılara yöneltilen "Sizce gönül rahatlı̆̆ıyla bir otelde tatil yapmak için salgının hangi ayda tamamen bitmesi gerekir?" sorusuna katılımcıların \%29,5'inin “Temmuz", \%28,1'inin “Haziran", \%22,7'sinin “Eylül” ve \%19,7'sinin ise "Ağustos" cevabını 
verdikleri görülmüştür. Onuncu soru olarak katılımcılara yöneltilen "Avrupa'ya seyahat planınızı en erken ne zaman düşünürsünüz?" sorusuna katılımcıların \%48,1'inin "Aşı bulunduktan sonra", \%32,4'ünün "Yeni yılda" ve \%19,5'inin ise "Kisıtlamalar kalkarsa hemen" cevabını verdikleri görülmüştür. Katılımcılara son soru olarak yöneltilen on birinci soru olan "Asya'ya seyahat planınızı en erken ne zaman düşünürsünüz?" sorusuna katılımcıların \%72,5'inin “Aşı bulunduktan sonra", \%17,4'ünün "Yeni yılda" ve \%10,1'inin ise "Kısıtlamalar kalkarsa hemen" cevabını verdikleri tespit edilmiştir.

\section{Turizm İşletmeleri Yöneticilerinin Tanımlayıcı Özellikleri}

Araştırmanın ikinci saha çalışması, Türkiye' de turizm faaliyetlerinin yoğun olduğu bölgeler olan Antalya ve Bodrum'daki turizm işletmelerinin çeşitli yönetim pozisyonlarında görev yapan yöneticilere uygulanmıştır. Her birine birer verilen yöneticilerin tanımlayıcı özellikleri aşağıdaki tabloda sunulmuştur.

Tablo 3. Turizm İşletmeleri Yöneticilerinin Tanımlayıcı Özellikleri

\begin{tabular}{|l|l|l|c|l|}
\hline \multicolumn{1}{|c|}{ Katılımcı } & \multicolumn{1}{|c|}{$\begin{array}{c}\text { Sektördeki Faaliyet } \\
\text { Alanı }\end{array}$} & \multicolumn{1}{|c|}{$\begin{array}{c}\text { Çalışma } \\
\text { Bölgesi }\end{array}$} & $\begin{array}{c}\text { Sektördeki } \\
\text { Çalışma Yılı }\end{array}$ & \multicolumn{1}{c|}{ Pozisyonu } \\
\hline K-1 & Butik Otel & Bodrum & 14 & Genel Müdür \\
\hline K-2 & Her Şey Dahil & Antalya & 33 & Genel Müdür \\
\hline K-3 & Tatil Köyü & Bodrum & 19 & Rezervasyon Müdürü \\
\hline K-4 & Butik Otel & Bodrum & 22 & İşletme Sahibi \\
\hline K-5 & Tatil Köyü & Antalya & 25 & Genel Müdür \\
\hline K-6 & Her Şey Dahil & Antalya & 42 & Ön Büro Müdürü \\
\hline K-7 & Her Şey Dahil & Antalya & 38 & Genel Müdür \\
\hline K-8 & Her Şey Dahil & Antalya & 29 & Genel Müdür \\
\hline K-9 & Her Şey Dahil & Bodrum & 27 & Genel Müdür \\
\hline K-10 & Her Şey Dahil & Bodrum & 44 & Genel Müdür \\
\hline K-11 & Her Şey Dahil & Bodrum & 40 & Genel Müdür \\
\hline K-12 & Her Şey Dahil & Bodrum & 19 & Genel Müdür \\
\hline K-13 & Her Şey Dahil & Bodrum & 24 & Genel Müdür \\
\hline K-14 & Her Şey Dahil & Bodrum & 35 & Genel Müdür \\
\hline K-15 & Her Şey Dahil & Antalya & 39 & Genel Müdür \\
\hline K-16 & Her Şey Dahil & Antalya & 37 & Genel Müdür \\
\hline K-17 & Her Şey Dahil & Antalya & 42 & Rezervasyon Müdürü \\
\hline K-18 & Her Şey Dahil & Antalya & 31 & Genel Müdür \\
\hline K-19 & Butik Otel & Antalya & 20 & İşletme Sahibi \\
\hline K-20 & Tatil Köyü & Antalya & 26 & Genel Müdür \\
\hline
\end{tabular}

Tablo 3'te turizm işletmeleri yöneticilerinin sektördeki faaliyet alanları incelendiğinde Bodrum'dan 9, Antalya'dan ise 11 katılımcının olduğu görülmektedir. Katılımcılarının 14'ünün "Her Şey Dahil”, 3'ünün "Tatil Köyü", 3'ünün ise "Butik Otel” faaliyet alanında oldukları görülmektedir. Katılımcıların 15'i “Genel Müdür", 2'si “İşletme Sahibi”, 2'si "Rezervasyon Müdürü", 1'i ise "Ön Büro Müdürü" pozisyonunda oldukları görülmektedir. Katılımclların sektör deneyimlerinin oldukça yüksek olduğu, çalışma sürelerinin ise ortalama 30,03 yıl olduğu görülmektedir. 
Özetle, çalışmaya dâhil olan katılımcıların ağırlıklı olarak "erkek", "26-44" yaş aralığında, "lisans" mezunu, "evli", "çalışan" ve "3501-4500 TL" gelir grubundaki katılımcilardan oluştuğu görülmektedir. Bu bulgulara göre, katılımcıların genellikle orta yaşlı, orta gelirli ve çalışan kesimden oluştukları söylenebilir. Katılımcıların turizm taleplerine yönelik sorulara verdikleri cevaplar incelendiğinde, katılımcıların kendilerine sorulan "Tüm seyahat kısıtlamalarının 15 Haziran'da kaldırıldığını varsayarsak, ne kadar kısa sürede uçuş içeren bir yurt içi seyahate çıardınız?" sorusuna katılımcıların \%31,5'inin en çok oranla "hemen" şeklinde cevap verdikleri görülmüştür. Dolayısıyla katılımcıların yaklaşık üçte birinin seyahat kısıtlamaları kalkar kalmaz uçuş içeren bir yurtiçi seyahate çıkmaya hazır oldukları görülmektedir. İkinci olarak katılımcılara sorulan “Tüm seyahat kısıtlamalarının 15 Haziran'da kaldııldığını varsayarsak, çıkacağınız ilk yurtiçi seyahatinizde hangi ulaşım aracından yararlanmayı düşünürsünüz?" sorusuna katılımcıların \%63,0'ının "Özel araç" cevabını verdikleri tespit edilmiştir. Buradan hareketle, katılımcıların yaklaşı üçte ikisinin Covid-19 nedeniyle yurtiçi seyahatlerini özel araçları ile gerçekleştirmek istedikleri belirtilebilir. Üçüncü olarak katılımcılara sorulan "Tüm seyahat kısıtlamalarının 15 Haziran'da kaldırıldığını varsayarsak, yurtiçi tatile çıkmayı düşünür müsünüz?" sorusuna katılımcıların \%65,0'ının "Evet" yanıtını verdikleri saptanmıştır. Bu noktada, katılımcıların yaklaşık üçte ikisinin 15 Haziran'da seyahat kısıtlamalarının kalkması durumunda yurtiçi tatile çıkmak için hazır oldukları anlaşılmaktadır. Dördüncü olarak katılımcılara sorulan “Tüm seyahat kısıtlamalarının 15 Haziran'da kaldırıldığını varsayarsak, tatil planınız için bir seyahat acentasından yararlanmayı düşünür müsünüz?" sorusuna katılımcıların \%56,5'inin "Kararsızım" cevabını verdikleri tespit edilmiştir. Buradan hareketle, katılımcıların yarısından fazlasının 15 Haziran' da seyahat kısıtlamalarının kalkması durumunda tatil planı için bir seyahat acentasından yararlanmak konusunda kararsız kaldıkları, tatil planları için seyahat acentalarından bağımsız veya yarı bağımsız bir tatil planı oluşturmak istedikleri söylenebilir. Beşinci olarak katılımcılara sorulan "2020 yaz sezonu bitmeden bir otelde tatil yapmayı planlıyor musunuz?" sorusuna katılımcıların \%39,4'ünün "Hayır" cevabını verdikleri tespit edilmiştir. Bu sonucun, bir önceki soruda ulaşılan "katılımcıların seyahat acentalarından bağımsız veya yarı bağımsız bir tatil planı oluşturmak istedikleri" sonucunu destekler nitelikte olduğu dikkat çekmektedir. Altıncı olarak katılımcılara yöneltilen "2020 yaz sezonu bitmeden bir otelde tatil yapmayı planladığınızı varsayarsak, tatil yapmak için tercih edeceğiniz otel aşağıdakilerden hangisi olur?" sorusuna katılımcıların \%33,9'unun "Apart/Pansiyon" yanıtını verdikleri saptanmıştır. Bu sonuç da beşinci ve altıncı sorularda ulaşılan "seyahat acentalarından bağımsız veya yarı bağımsız bir tatil planı oluşturma" sonucunu destekler nitelikte olup, katılımciların 2020 yaz sezonu bitmeden bir otelde tatil yapmayı planlamaları durumunda otel işletmelerinden ziyade daha küçük ölçekli olan apart/pansiyon konaklama türünü tercih edeceklerini göstermektedir. Yedinci olarak "2020 için otel rezervasyonu yaptırdınız mı?" sorusuna katılımcıların \%68,6'sının "Hayır, yaptırmadım" cevabını verdikleri görülmüştür. Bu sonuç da yine önceki soruların sonuçlarını destekler nitelikte olup, katılımcıların büyük bir çoğunluğunun 2020 için otel rezervasyonu yaptırmadıklarını göstermektedir. Sekizinci olarak katılımcılara yöneltilen "Otellerin sertifikalarına ne derece güvenirsiniz?" sorusuna katılımcların \%35,9'unun "Kararsızım" yanıtını verdikleri görülmüştür. Dolayısıyla katılımcıların yaklaşık üçte birinin otel sertifikalarına güvenme konusunda kararsız kaldıkları anlaşılmaktadır. Dokuzuncu olarak katılımcılara yöneltilen "Sizce gönül rahatlı̆̆ıyla bir otelde tatil yapmak için salgının hangi ayda tamamen bitmesi gerekir?" sorusuna katılımcların \%29,5'inin "Temmuz" cevabını verdikleri görülmüştür. Bu sonuç, katılımcıların yaklaşık üçte birinin salgının temmuz ayında bitmesi durumunda gönül rahatlı̆̆ıyla bir otelde tatil yapma isteklerinin olduğuna işaret etmektedir. Onuncu olarak katılımcılara yöneltilen "Avrupa'ya seyahat planınızı en erken ne zaman düşünürsünüz?" sorusuna katılımclların \%48,1'inin "Aşı bulunduktan sonra" cevabını verdikleri görülmüştür. Bu sonuç, katılımcıların yaklaşık yarısının 
en erken ancak aşı bulunduktan sonra Avrupa'ya seyahat planı yapacaklarını göstermektedir. Katılımclara son olarak sorulan "Asya'ya seyahat planınızı en erken ne zaman düşünürsünüz?" sorusuna ise katılımcıların \%72,5'inin "Aşı bulunduktan sonra" cevabını verdikleri tespit edilmiştir. Bu sonuç, Covid-19'un ilk olarak ortaya çıktığı Çin'in de içerisinde yer aldığı kıta olan Asya kıtasına yönelik katılımcıların seyahat planlarını en erken ancak aşı bulunduktan sonra yapmayı düşündüklerini göstermektedir.

\section{BULGULAR ve DEĞERLENDİRME}

Bulgular ve değerlendirme, turizm işletmeleri yöneticilerinin Türkiye'de Covid-19 salgını öncesinde iç pazara ilişkin değerlendirmelerini ve Türkiye'de Covid-19 salgını süreci ve sonrası için iç pazara ve turizme ilişkin değerlendirmelerini kapsamaktadır.

\section{Türkiye'de Koronavirüs (Covid-19) Salgını Öncesinde Turizm İşletmeleri Yöneticilerinin İç Pazara İlişkin Değerlendirmeleri}

Turizm işletmeleri yöneticilerinden ilk olarak Koronavirüs (Covid-19) salgını öncesinde iç turizm pazarını değerlendirmeleri istenmiştir. Katılımcılardan K-7 "İç pazarda kısa sürede 10 milyon kişiye ulaşma isteğimiz var. Çünkü bizler iç pazarı her zaman en önemli kaynak pazarımız olarak görmekteyiz. 80 milyonluk nüfusumuz var. Ülkemizde kişi başı gelirlerinin de her geçen yıl arttı̆̆ı görülmekte. Bu anlamda turizm sektörü olarak elimizde hazır bir potansiyel var. Bu potansiyeli yalnızca kıyllarda tatil anlamında düşünmemek gerek. Bunu, Türkiye'de var olan tüm turizm ürünlerinde kullanılabilecek bir potansiyel olarak düşünmemiz gerek. Sürdürülebilir bir turizm anlayışı kapsamında iç pazar bizim açımızdan vazgeçilmez kaynaklardan bir tanesi. Turizmin 12 aya yayılması için gerekli olan bir diğer unsur, yine iç pazarın güçlü ve dinamik tutulmasıdır. Burada bizim en büyük arzumuz, iç pazarın payını toplam turizm hareketleri içinde \%30'lara getirmek. Böylece geleceğe çok daha güvenle ve umutla bakabiliriz."

Katılımcılardan K-12 ise iç pazara yönelik düşüncelerini "Sektörde yer alan kalifiye elemanlarm tutulması, tesislerin devamlılığının sağlanması ve hizmet standartlarının korunması bağlamında iç pazar her zaman önem arz etmektedir. Çünkü biz, iç pazarı her zaman en önemli kaynak pazarımız olarak görmekteyiz." şeklinde ifade etmiştir.

Katılımcılardan K-20'nin ise iç pazar ile ilgili "Yerli turist Türkiye'de her zaman kurtarıcı olmuştur. Ne zaman ki yatak sayısı artsa, dış pazarda bir durulma veya kriz olsa, yerli turist piyasadaki boşluğu doldurmuş ve piyasanın nefes almasını sağlamıştır." şeklinde düşüncelerini belirtmiştir.

K-17 ise iç pazara yönelik düşüncelerini "Otellerin maalesef yabancı turiste farkl, yerli turiste farklı fiyatlar uyguladıklarm görüyoruz. Ayrıca, yerli turistlerden talep edilen fiyatlarm yabancı turistlerden daha yüksek olması da cabası. Zaten yerli turistlerin bayram tatilleri dışında çok fazla tatile çıkmadıkları bilinmektedir. Odalarının boş kalmasını istemeyen otelciler de, sezon başında kontenjanlarının bir kısmını yerli ve yabancı tur operatörlerine satarak kendilerini garanti altına almaktadırlar. Varılan anlaşmadan sonra ise, oda fiyatlarında otelcilerin söz hakkı kalmamaktadır." şeklinde dile getirmiştir.

Katılımclardan K-3 ise konuya yönelik olarak düşüncelerini "Turizmin yerli ve yabancı olmak üzere iki yönü mevcut. Yabancı turistin Türkiye' ye ilave döviz getiren bir imkân olması nedeniyle konumu bir yerde yerli turistten ayrıdır. Öte yandan turizm sektöründe yaşanan krizlerde yerli turistin çok büyük desteği oluyor. Ancak ne olursa olsun otellerin ayakta kalması, güçlü bir şekilde yarılara yoluna devam edebilmesi ve bir çekim merkezi olabilmesi açısından yerli ve yabancı misafir ayrımının turizm açısından 
çok fazla yapılmaması gerektiğini düşünüyorum. Yabancı ziyaretçilere yönelik ilginin aynı şekilde yerli ziyaretçilere de gösterilmesi gerekmektedir. Bakın bazen ziyaretçi bazense misafir tabirlerini kullanıyorum, bunları bilinçli olarak yapıyorum. Aslında her turistin aynı zamanda bir misafir olduğu; ülkemizin, şehrimizin veya konaklama tesisimizin misafiri olduklar unutulmamahdır. Turistlere "misafir" gözüyle bakarsak daha hızlı bir gelişim sağlamış oluruz." şeklinde ifade etmiştir.

K-1 ise konuya yönelik düşüncelerini şu sözlerle dile getirmiştir: "Bizim ülkemizde turizm sektörü müşterilerine yerli, yabancı ayrımı yaparak çifte standart uygulamakta, yerli turiste üvey evlat muamelesi yapmaktadır. Turizm tesislerinin ayakta kalması, güçlü şekilde yoluna devam edebilmesi, çekim merkezi olabilmesi açısından yerli, yabancı turist ayrımı yapılmamalı. Yabancı turiste gösterilen ilginin aynı şekilde yerli turiste de gösterilmesi gerekmektedir."

İç pazara bakış konusunda yerli turist durumundaki tatilcilerin de dertli olduğuna işaret eden K14, "Her şey dâhil fiyatlarla satın alınan paket turların hem yabancı turistlere göre daha pahalı olduğunu hem de odaların pencerelerinin manzarasız kör bölgelere baktıklarını söylemek mümkün. Bununla birlikte broşür, ilan ve tanıtımlarda yer alan görsellerin de birçoğunun yanıltmaca olduğu aşikârdır. Son olarak her yıl binlerce yerli turistin kirli, yırtık çarşaflardan ve tesisteki açık büfe yemeklerinin kalitesizliğinden şikâyet ettikleri görülmektedir. Turizmcilerin ilk olarak kendi ülkesinin tatilcilerine önem vermeleri gerekmektedir. Bunun nedeni ise yabancı turistlerin en ufak bir olayda sırtlarım dönmelerine karşın yerli turistin ise vefakârlı̆̆lyla tekrar ayn yere geldiği ve hatta ayaklı reklam unsuru gibi kaldı̆̆ tesisi övmesidir." sözleriyle düşüncelerini ifade etmiştir.

Son olarak konuya yönelik K-6 "Tesis sahipleri ve turizmcilerin yerli ve yabancı ayrımının sürdüğ̈̈nü söylemek mümkün. Erken rezervasyon imkânı olsa dahi Türk turiste yönelik farkl fiyat uygulamalarmın artış göstererek sürdüğ̈̈ dikkat çekiyor. Türk turistlerin rezervasyon yaptırdıklarında üç katı fiyat çekildiğ $i$ de ortada. Sezon öncesinde ortalama 500-1000 lira civarındaki günlük odalarm, sezon ortasında 2000 liranın üzerinde satıldığı gerçeği var. Yabancı turistlerin yurt dışı acentalar aracılı̆̆ıyla gelmeleri sebebiyle bu fiyatların üçte birini ödeyerek tatil yaptıkları bir diğer gerçek. Yabancı turistler açısından kurun yüksek olması da ayrı bir avantaj. Böylece yabancı turistler dünya ortalamalarını çok daha altında fatura ödüyorlar. Çünkü Türkiye'deki otellerin fiyatları kur ve döviz ile belirleniyor."

Özetle, turizm işletmeleri yöneticilerinin Covid-19 salgını öncesinde iç pazara yönelik değerlendirmeleri incelendiğinde, turizm uygulayıcılarının bu pazarı geliştirmek istemelerine rağmen, dış pazara kıyasla iç pazara yönelik daha olumsuz bir bakış açısına sahip oldukları anlaşılmaktadır. Bu durumun temel nedeninin diş turizm pazarının ülkeye döviz kazandırması ile ilgili olduğu ifade edilebilir.

\section{Türkiye'de Koronavirüs (Covid-19) Salgını Süreci ve Sonrası İçin İç Pazara ve Turizme İlişkin Değerlendirmeler}

Çalışmada ikinci olarak, turizm işletmeleri yöneticilerinden Koronavirüs (Covid-19) salgını süreci ve sonrası için iç pazarı ve turizm sektörünü değerlendirmeleri istenmiştir.

K-19 konuya yönelik olarak; "Bu süreçte iç pazarın kurtarıcı olacağı düşüncesi hâkimdir. Örneğin, 2019 yılında normale dönünce birazcık bir toparlanmanın ardından iç pazara yönelik yüksek fiyatlar sunulmuştur. İç pazarın kurtarıcı olması isteniyorsa, fiyatların orta-yüksek gelir grubuna göre ayarlanması sektör açısından yararlı olacaktır. Yerli misafir zaman zaman daha yüksek ödeme yaptığı gerekçesiyle de şikâyette bulunmaktadır. Sadece kriz dönemlerinde değil; her zaman anlamaya, tüketici beklentilerini tasarlamaya ve Anadolu insanına yönelik paket ve ürünler sunmaya gayret edelim. Çünkü 
ilk kurtarıcı ve şu anki mevcut gerçeklere göre ulaşılabilecek yegâne ve en önemli kitle onlardır. Türk insanında da artık bir tatil ve turizm alışkanlığı var. Turizm onlar açısından da zorunlu bir gereksinimdir. Covid-19 sürecinde yurt içi ve dışında yapılan pek çok anket ve ilgili hükümet yetkililerinin söylediği şey şudur: öncelikle iç turizm pazarında bir hareketliliğinin başlayacağıdır. Hem havayolu ulaşımının kullanılmaması hem de săğlk, güvenlik, hijyen vb. nedenlerle insanların kendi ülkeleri içinde seyahat edeceği algısı hakimdir. Çalı̧an ve askıdaki tüm nüfusun kademeli olarak üretime dönmesi, emek yoğun bir sektör olan turizm açısından oldukça önemliyse; bu anlamda iç pazar gerçekten kurtarıcı olabilir." şeklinde ifadelerde bulunmuştur.

Konuya yönelik K-10 ise düşüncelerini; "Covid-19 pandemisinin bugüne kadarki geniş çaplı etkisi ve normalleşme sürecinin de zaman alacak olması gerekçesiyle 2020'nin yabancı turist bağlamında kayıp bir yıl olacağı varsayımı ile hareket edebiliriz. Bu anlamda öncelikle ülke insanımızın güveninin kazanılması daha kolay ve önemlidir. Bu nedenle yerli turiste, diğer adıyla iç pazara yönelik senaryolar hazırlığı içinde olunması zaruridir." şeklinde belirtmiştir. Konuya yönelik olarak K-10 ile benzer düşüncelere sahip olan K-8; "Antalya ve Muğla destinasyonları şüphesiz Covid-19'dan en çok etkilenecek destinasyonlarımı olacaktır. Covid-19'un yıkıcı etkisi bu destinasyonlarımızın turizm paradigmalarının değişmesine sebebiyet verecektir. Bu noktada bilhassa iç turizm pazarına yönelik stratejilerin yenilenmesi ve yeni bir anlayışın gündeme getirilmesi kaçınılmaz görünmektedir." şeklinde düşüncelerini belirtmiştir.

K-16 ise düşüncelerini "Haziran ayı ile birlikte turizm sektörü sezonu açmayı planlarken, sektörün kurtarıcısının yine yerli turist olacağı aşikârdır. Bu yıl özellikle Akdeniz Bölgesi'ndeki tesislerin \%60'ının açılacağı öngörülürken, gelirdeki azalmanın ve pandeminin de etkisiyle iç pazardaki turizm rakamlarının 2 milyon civarında azalacağı tahmin edilmektedir. İkinci çeyreğini de tamamıyla kapalı olarak geçiren sektörün iç pazar kaybının \%30'larda olacağını ifade edebilirim. Buna ek olarak seyahat acentaları aracılı̆̆ılla hareket eden yıllık 8 milyon civarında bir iç pazar mevcut. Bu yıl \%30'larda kayıp yaşanacağ göz önüne alındı̆̆ında, iç pazar hacminin bu yıl için 5,5-6 milyon civarında olacağı belirtilebilir." şeklinde ifade etmiştir.

Konuya yönelik olarak K-8, K-10 ve K-19'dan farklı bir bakış açısına sahip olan ve Koronavirüs (Covid-19) salgını sürecinde iç pazarın kurtarıcı olmayacağını ifade eden K-5 düşüncelerini şu şekilde ifade etmiştir; "Yerli turiste yönelik beklentilerimiz tabii ki var ama yerli turistlerin ortalama konaklama gecesi 4 gece şeklinde gerçekleşmektedir. Kıyı kesimi için 4 gece oldukça kısa bir konaklama süresi. Yerli turistlerin sayısı artsa bile ortalama konaklama sürelerinin sezon başında çok artamayacak olması nedeniyle faydası olur ancak kurtarıcı olmaz. Yerli turist rakamlarının geçen yılın \%40'ı üzerinde oluşacağın düşünsek de özellikle Rusya ve Avrupa pazarından eksilen rezervasyonlar kapatacak büyüklükte olmayacağını söyleyebiliriz. Bu sebeple de yerli turistin sektörün kurtarıcısı olmadı̆̆ını belirtebiliriz."

Dünya tarihinde yakın bir dönemde Covid-19 krizine benzer bir kriz ile karşılaşılmadığını, bu nedenle yetkili otoritelerin hızlı ve etkili bir şekilde refleks vermekte zorlandıklarını ifade eden K-2 konuya yönelik düşüncelerini; "Bu yıl için dış turizm pazarını tamamıyla unutup 2021 yılına yönelik stratejilerimize odaklanmalıyı. Yerli turiste ilişkin umudum olsa da turizm gelirlerinin ülke sınırlar içerisinde dönmesi çok bir şey ifade etmemekte. Yurtdışından gelen yabancı turistlerle beraber ülkeye ciddi bir döviz girdisi de geliyordu ki cari açı̆̆ın büyük bir kısmını turizm ile kapatabiliyorduk, krizin bitmesiyle birlikte ikili ilişkilerde de siyasi bir sorun olmaz ise açılacak ilk pazar Rusya olacaktır. Türkiye, Rus turistlerin gözünde bir numaral destinasyondur." şeklinde ifade etmiştir. 
Konuya yönelik olarak K-9 ise düşüncelerini; "Tesislerimizi açıp yerli turistle dolduralım demek tabii ki yanlış. Yerli turiste yüklediğimiz sorumluluğun oldukça büyük olduğunu söylemek mümkün. Türkiye'de turizmin çarklarının dönebilmesi için yerli turiste ihtiyacımız olsa da buna ek olarak ilave destek de gerekmektedir. Devletimiz iç hat uçuşlarında KDV'yi \%1'e indirdi. Sezonun bayram sonrasında açılacağın dü̈şünüyoruz. İç pazardaki açılımın daha hızlı bir biçimde gerçekleşmesini arzuluyorsak KDV'ye yönelik desteğin 2020 yılsonuna kadar uzatılması gerektiğini düşünüyorum. Ayrıca KDV indiriminin karayolu taşımacılığında da uygulanması gerektiğini ifade edebilirim. Bununla birlikte İtalya'nın, iç pazar hareketlerinin hızh başlaması için vatandaşlarına 500 Euro teşvik vermeye hazırlandığıın görüyoruz. Türkiye'de de buna benzer bir çalışma yapılabilir. Bu, Covid-19 sürecinde gelir ve işlerinde büyük azalmalar olan, karantina sürecinde bunalan insanlarmmza büyük bir moral ve motivasyon kaynağı olacaktır." şeklinde ifade etmiştir.

K-11 ise konuya yönelik düşüncelerini “Bugüne kadar turizm sektörünün çok büyük krizler yaşadığını, ancak bu krizlerin hepsinden daha çok güçlenerek çıktı̆̆ın belirtebilirim. Covid-19 krizinin de Türkiye için böyle olacağın düşünüyorum. 2016 ve 2017 yıllarında yaşadığımız zor dönemlerde yerli turistin çok büyük desteğini gördük. 2020 de kriz senesi ve pandemi sonrasinda yerli turistin hareketliliğiyle sektörün yavaş yavaş bir normalleşme sürecine gireceği aşikâr. Türkiye turizm sektörü oldukça güçlü, birkaç aylık bir krizle yerle bir olmamız söz konusu değil, elbette bunun da altından kalkacağız." şeklinde belirtmiştir. Son olarak K-4 ise konuya yönelik düşüncelerini "Türk turistlerle ülkemizdeki bütün otelleri doyurmamız imkânsız. Yabancı turistin gelmesini bekleyecek, bu süre zarfinca açılmayacak tesislerin olacă̆ını öngörüyorum. Bu zamana kadar yerli turiste önem vermeyen tesislerin bu sene biraz zorlanacaklarını düşünüyorum. Turizm Bakanlı̆̆ı'nın \%50 veya \%60 kapasite sinırlaması getirebileceği konuşuluyor. Tesislerin yarısının açılmadığı, açılan tesislerin de \%50 kapasite ile hizmet verdiği bir ortamın oluşacağı düşünülürse fiyatların düş̧mesinin de beklenmesi yanlış olur." şeklinde ifade etmiştir.

Koronavirüs (Covid-19) salgını süreci ve sonrası için turizme yönelik değerlendirmeleri istenen katılımcılardan K-5, "Her şey dâhil sistemin tamamıyla revize edileceğini, hatta yavaş yavaş azalarak yok olabileceğini" belirtmiştir. "Covid-19 ile birlikte artık insanlar binlerce kişinin bulunduğu tesislerde,

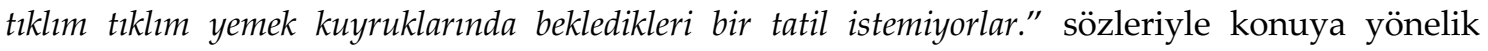
düşüncelerini dile getiren K-5, Koronavirüs (Covid-19) salgını sonrasında her şey dâhil otellerin konseptlerinin de değişikliğe gideceğini, mutfaklarının butikleşeceğini ve alakart sisteme geçeceklerini belirtmiştir. K-5 ayrıca, "tıklım tıklım” plaj anlayışının da geçmişte kalacağını, "2 metrekareye 1" şartı ile şezlongların bu mesafede konumlandırılabileceğini belirtmiş ve "Bundan böyle belki de plaj ve restoranlara da saatle gireceğiz" sözleriyle düşüncelerini ifade etmiştir.

K-9 ise değişikliğe gidilen konseptlere ek olarak artan maliyetlerin ulaşım ve konaklama hizmetlerinin fiyatlarını artıracağını, bu artışın da tur fiyatlarına yansıyacağını belirtmiş ve konuya yönelik düşüncelerini "Havayolu fiyatları kesinlikle artacak, çünkü uçağın veya alınan mazotun maliyeti de değişmiyor. Bununla birlikte personel masrafların ne kadar azaltabilirsiniz ki? Sonuç olarak maliyetler aynı, ancak bu maliyet 185 yolcuya bölünmek yerine 90 veya 100 yolcuya bölünecek. Bu da fiyatların ortalama iki katı kadar artacağı anlamına gelmektedir." sözleriyle ifade etmiştir. Yeni süreçte insanların tatil anlayışına yönelik bakış açılarının da değişeceğini belirten K-1, "denizkum-güneş" üçlüsünden ziyade "daha spesifik" tatil alternatiflerine yönelineceğini belirtmiştir. K-1 konuya yönelik düşüncelerini; "İnsanlarm bu süreç itibariyle dă̆ turizmi, trekking veya kültür turları gibi alternatif turlara kayacakların düşünüyorum. Kısaca "daha tenha" olarak adlandırlabilecek turlara yöneleceklerini belirtebilirim." sözleriyle ifade etmiştir.

Covid-19 sonrasında kişilerin tatil amaçlı seyahatlerini özel araçlarıyla gerçekleştirmek isteyeceklerini belirterek buradan hareketle Türk turizmcilerin de komşu ülkelere yönelmeye 
başlayacaklarını öngören K-2, “Yunanistan'a bakacağız, Romanya, Bulgaristan, Balkan'a. Rahat gelebilecek olan Gürcistan, Rusya'ya bağ̆ı Soçi ve o bölgelere. Bunun yanı sıra İran, ilişkilerimizi düzeltirsek Suriye, Irak ve belki de Arap ülkelerinden arabayla gelişler artacak. Açıkçası yönümüzü biraz onlara doğru çevireceğiz." sözleriyle konuya yönelik düşüncelerini ifade etmiştir.

K-20 ise; "Artık tatil seçimlerinde "sağlık" ve "hijyen" unsurlarının eskisinden çok daha fazla önem taşıyacağı herkesin ortak öngörüsüdür. Sağlık ve hijyen unsurlarının önemli oluşu sadece fiziksel temizlik rutinlerini etkileyecek bir durum değildir. Diğer sektörlerde olduğu gibi turizm sektöründe de tüketici alışkanlıklarında büyük değişimlerin yaşandığı görülmektedir. Eskiden olduğu gibi kalabalık grupların bir araya geldiği, birbirlerini tanımayan insanların buluşmasını sağlayan kutlamalar, düğ̈̈̈nler ve partiler gibi benzeri etkinliklerin ve bu etkinliklere yönelik organize edilmiş alanlara olan talep düştü. Yeni düzene göre "daha küçük" ve "samimi" gruplara yönelik özel fiziksel yapılara ve bu gruplara yönelik birbirinden bağımsız hizmet verebilecek sistemlere olan talep arttı. Örnek vermek gerekirse; pandemi döneminde evlenenler 1000 davetliyi ağırlayacak bir dü̆̆̈̈n organizasyonundan ziyade küçük gruplar halinde birden fazla butik kutlamalara yönelmeye başlamışlardır. Sistemin temelden sarsılmasına yol açan bu yeni anlayış, gerek mimari yapı gerekse hizmet şekillerine yönelik yepyeni kararların alınmasına sebep olmaktadır. Artık tek seferde daha çok misafirin ağırlanacağı dev salonlar veya havuzlar yerine küçük gruplara yönelik özel alanları, bu alanların sosyal mesafe kurallarına göre tasarlanmasını ve alanı kullananlara yönelik sunulan hizmetteki hijyenik standartlarını konuşacağız. Uluslararası seyahat kısıtlamaları nedeniyle de birçok ülkede iç turizm faaliyetlerinin yoğunlaşacağını, ülke içerisinde dolaşıma yönelik taleplerde artış olacağını, ulaşım, konaklama süresi gibi konularda da bu taleplere yönelik yeni alı̧kanlıklar doğacă̆ın söyleyebiliriz." sözleriyle konuya yönelik düşüncelerini ifade etmiştir.

K-3 konuya yönelik düşüncelerini; “Covid-19'un etkisinin azalmaya başlamasıyla beraber, iç turizme yönelik hareketliliğin başlaması için devletimizin kamu ve özel bütün çalı̧̧anlarına izin konusunda "esnek" ve "destek" olması gerekmektedir. Devletimizin bu konuda iç turizmi canlandıracak teşvik ve destekler açıklaması gerektiğini düşünüyorum. Covid-19 süresi zarfınca büyük fedakârlıklar gösteren tüm sağlık çalışanlarımıza yönelik devlet destekli özel kampanya veya promosyonların yapılması, buna ek olarak sağllk çalışanlarının aileleri ile birlikte çok uygun şartlar altında tatil yapmalarına imkân tanınmalıdır." şeklinde ifade etmiştir.

K-18 ise konuya yönelik düşüncelerini; “Turizmde Türkiye'nin önünde gelen ülkelerin tersine Türkiye'nin turizm gelirlerinin yerli turistten ziyade yabancı turistten să̆lanması nedeniyle Türkiye'de turizm hareketliliğinin başlaması noktasında dış dünyaya bağlı bir durumda olduğunu belirtebiliriz. Türkiye, Covid-19 savaşını kazanmak üzere olsa da yurt dışından turist gelmesi için onların da sağlıklarına kavuşması gerekmekte. Türkiye açısından bu hareketliliğin iç turizmde en erken haziran sonu olması öngörülmektedir. Bu şartlar altında, 2020 yılının turizm hareketliliğinin en iyi ihtimalle yılın son çeyreğine sıkışıp kalacak olması nedeniyle Türkiye'nin 2021'e yönelik tanıtım ve PR çalışmalarına şimdiden önemle eğilmesi gerekmektedir. Otelcilik alanında bu süreçten önce yalnızca yiyecek ve içecek ile mutfak departmanından istenen zorunlu hijyen sertifikalarının artık tüm turizm bileşenlerinden istenmesi ve devletin de bunu destekleyeceği görülmektedir. Bu özel durumun, Türkiye'yi tanıtıcı PR çalışmalarında da kullanılması gerekmektedir." şeklinde ifade etmiştir.

Son olarak K-7 konuya yönelik düşüncelerini; "Müzelerdeki açılış ve kapanış saatlerinin tekrar düzenlenmesi gerekmektedir. Yurt dışındaki uygulamalarda olduğu gibi Türkiye'de de müze biletlerinin "randevulu sistem" aracılığıyla kişilere özel olarak belirlenecek saatlerde satışı yapılmalı ve böylece oluşması muhtemel kalabalı̆̆ın engellenmesi sağlanmalıdır. Bu uygulaya ek olarak yılsonuna kadar müzeler, ören yerleri gibi mekânlarda yerli turistlere indirimler yapılmalıdır. Yine, her şey dahil sistemi, açık büfelerin konseptleri, havuz ve plajlarm kullanımlarma yönelik konular devlet eliyle yeniden 
düzenlenmeli, bu düzenlemeler katiyen işletmelere bırakılmamalıdır. Bütün tesisler ve ulaşım araçlarına yönelik "sağllk", "hijyen" ve "güvenlik" kriterlerinin yeniden belirlenmesi ve standartlara uyan işletmelerin sertifikalandırılması gerekmektedir. Özelikle günümüzde turistik ürün satın alacak yerli ve yabancı turistler doğrudan seyahat acentalarına gitmek yerine, satın alma işlemlerini çevrimiçi kanallar aracılı̆̆gyla gerçekleştirmektedirler. Bu sebeple özel sektör temsilcileri ile birlikte devletimizin de bu konulara yönelik altyapıya daha çokönem vermeleri gerektiğini düşünüyorum." sözleriyle ifade etmiştir.

Özetle, turizm işletmeleri yöneticilerinin Covid-19 salgını süreci ve sonrası için iç pazara yönelik değerlendirmeleri incelendiğinde, Türkiye'deki turizm uygulayıcılarının ağırlıklı olarak iç pazarı 2020 Türkiye turizm sezonunun kurtarıcısı olarak gördükleri ve Türkiye turizminin çarklarının dönmesi için iç pazar hareketlerine ihtiyaç duydukları anlaşılmaktadır. Öte yandan, turizm işletmeleri yöneticilerinin kriz ortamı geçince de otel fiyatlarının hemen arttırılmasının doğru olmadığını ve iç pazara gereken değerin verilmesi gerektiğini belirttikleri görülmüştür.

\section{SONUÇ, TARTIŞMA ve ÖNERİLER}

OECD ülkelerinde iç turizm pazarının büyüklüğünün \%77, Fransa ve İtalya'da ise \%65 düzeyinde olduğu görülmektedir (Turizm Bakanlığı, 2017). Türkiye'de ise \%13-15 seviyesinde bir iç turizm pazarının varlığından söz edilmektedir. İç turizm pazarı da her ne kadar sınırlama önlemlerinden etkilense de kriz sonrasında iç turizm pazarında daha çabuk bir toparlanma öngörülmektedir (OECD, 2020). Bu çalışma kapsamında ulaşılan sonuçların da söz konusu beklentiyi destekler nitelikte olduğu görülmektedir. Şayet, katılımcıların kendilerine sorulan “Tüm seyahat kısıtlamalarının 15 Haziran'da kaldırıldığını varsayarsak, ne kadar kısa sürede uçuş içeren bir yurt içi seyahate çıkardınız?" sorusuna katılımcıların \%31,5 gibi kayda değer bir bölümünün "hemen” yanıtını verdikleri görülmüştür. Bu kapsamda çalışmada, iç pazarın turizm talebi göz önüne alınarak turizm yöneticilerinin iç pazara gereken önemi vermesi ve fiyatların iç pazarın yararlanabileceği şekilde revize edilmesi gerektiği önerilebilir. Bununla birlikte iç turizm pazarının, yalnızca kriz süreçlerinde bir "kurtuluş" olarak görülmesinden ziyade, "sürekli değer verilen" bir pazar olması gerektiği belirtilebilir.

Turizm işletmeleri yöneticilerinin Covid-19 salgını öncesinde iç pazara yönelik değerlendirmeleri incelendiğinde, turizm uygulayıcılarının bu pazarı geliştirmek istemelerine rağmen, dış pazara kıyasla iç pazara yönelik daha olumsuz bir bakış açısına sahip oldukları anlaşılmaktadır. Bu durumun temel nedeninin dış turizm pazarının ülkeye döviz kazandırması ile ilgili olduğu ifade edilebilir.

Turizm işletmeleri yöneticilerinin Covid-19 salgını süreci ve sonrası için iç pazara yönelik değerlendirmeleri incelendiğinde ise, Türkiye'deki turizm uygulayıcılarının ağırlıklı olarak iç pazarı 2020 Türkiye turizm sezonunun kurtarıcısı olarak gördükleri ve Türkiye turizminin çarklarının dönmesi için iç pazar hareketlerine ihtiyaç duydukları anlaşılmaktadır. Ancak turizm işletmeleri yöneticileri tarafından iç pazarın kurtarıcı olması bekleniyorsa, turistik ürünlerin fiyatlarının orta ve yüksek gelir gruplarına göre ayarlanmasının turizm sektörü bağlamında faydalı olacağı vurgulanmıştır. Ayrıca, çalışan ve askıdaki kesimin aşamalı bir şekilde üretim faaliyetlerine dönmelerinin emek-yoğun olan turizm sektörü bağlamında oldukça önemli olması nedeniyle iç pazarın bu anlamda da gerçekten kurtarıcı olabileceği belirtilmiştir. Bununla birlikte az da olsa iç pazarın Covid-19 salgını sebebiyle dış pazarın eksilen rezervasyonlarını kapatacak büyüklükte olamayacağını, bu nedenle de yerli turistin sektörün kurtarıcısı olamayacağını belirten yöneticilerin de olduğu dikkat çekmektedir. 
Turizm işletmeleri yöneticilerinin Covid-19 süreci ve sonrasına ilişkin turizme yönelik değerlendirmeleri incelendiğinde ise, turizm işletmeleri yöneticilerinin Covid-19 sonrasında kitle turizminin popülaritesini yitireceğini ve butik otellere yönelik talebin ciddi bir şekilde artacağını belirttikleri görülmüştür. Ayrıca, hijyen şartlarının öne çıktığı bir konseptin diğer sektörlerde olduğu gibi turizm sektörü için de kaçınılmaz olacağı belirtilmiştir. Bununla birlikte yeni süreçte insanların tatil anlayışına yönelik bakış açılarının da değişeceği belirtilmiş, "deniz-kumgüneş"ten öte daha spesifik ve alternatif tatil seçeneklerine önem verileceği ifade edilmiştir.

Turizm işletmeleri yöneticilerinin yeni dönemde insanların tatil ulaşımlarını özel araçları ile gerçekleştirmeye yöneleceklerini öngörmeleri, bu çalı̧̧manın sonuçlarıyla da örtüşmektedir. Şayet katılımcılara sorulan “Tüm seyahat kısıtlamalarının 15 Haziran'da kaldırıldığını varsayarsak, çıkacağınız ilk yurtiçi seyahatinizde hangi ulaşım aracından yararlanmayı düşünürsünüz?" sorusuna katılımcıların \%63,0'ının “Özel araç” yanıtını verdikleri görülmüştür. $\mathrm{Bu}$ nedenle turizm işletmeleri yöneticilerinin Yunanistan, Romanya, Balkanlar, İran ve Arap ülkeleri gibi komşu ülkelerden özel araçla gelişlerin artacağını belirttikleri görülmüştür.

Turizm işletmeleri yöneticilerinin, Covid-19'un etkisini kaybetmeye başlamasıyla birlikte iç turizmin hareketlenmesi için hükümetin yeni bir planlama ile tüm çalışanlara (kamu, özel) izin konusunda esnek ve destek olması gerektiği ifade edilmiştir. Ayrıca hükümetin, yurtiçi turizmini canlandıracak teşvik ve destekler açıklamaları gerektiği, yine bu süreçte büyük fedakârlıklar yapan tüm sağlık çalışanları için devlet destekli özel kampanya ya da promosyonların yapılması gerektiği, sağlık çalışanlarının aileleriyle birlikte çok uygun şartlarda tatil yapmalarının sağlanması gerektiği belirtilmiştir. Bununla birlikte turizm işletmeleri yöneticilerinin 2021'in tanıtım ve PR çalışmalarına Türkiye'nin şimdiden önemle eğilmesi gerektiğini belirttikleri görülmüştür. Otelcilikte bundan önce sadece yiyecek ve içecek ile mutfak departmanından istenen zorunlu hijyen sertifikalarının artık tüm turizm bileşenlerinden isteneceği ve devletin de bunu destekleyeceği ifade edilmiş; bu özel durumun, Türkiye'yi tanıtıcı PR çalışmalarında da kullanılması gerektiği belirtilmiştir.

Yukarıdakilere ilaveten turizm işletmeleri yöneticileri tarafından müze açlış-kapanış saatlerinin yeniden düzenlenmesi gerektiği, yurt dışında olduğu gibi Türkiye'de de müze biletlerinin randevulu sistem ile kişiye özel belirlenen saatlerde satılması ve bu sayede oluşabilecek kalabalığın önüne geçilmesi gerektiği belirtilmiştir. Bu uygulamanın hızlıca hayata geçirilmesine ek olarak, 2020 yılı sene sonuna kadar müze, ören yeri vb. yerlerde iç turizme yönelik indirimlerin yapılması gerektiği ifade edilmiştir. Bununla birlikte her şey dahil sistemi, açık büfe konseptleri, havuz ve plaj kullanımları gibi önemli konuların devlet tarafından tekrar düzenlenmesi gerektiği belirtilmiş ve bunun kesinlikle işletmelerin inisiyatifine bırakılmaması gerektiği öne sürülmüştür. Ayrıca, tüm konaklama tesisleri ve transfer araçları için sağlık, hijyen ve güvenlik kriterlerinin yeniden belirlenmesi gerektiği ifade edilmiş, standartlara uyan işletmelerin sertifikalandırılmaları belirtilmiştir. Buna ek olarak, günümüzde turizm hizmeti almak isteyen iç ve dış turistlerin acentalara direk gitmek yerine, turizm hizmeti alımlarını çevrimiçi kanallar üzerinden gerçekleştirmeleri nedeniyle gerek özel sektör temsilcilerinin gerekse hükümetin bu konudaki altyapılara daha fazla önem vermeleri gerektiği öne sürülmüştür.

Çalışma sonuçlarından hareketle, Covid-19 krizi değerlendirilirken ve krizin bitiş süreci öngörülmeye çalışılırken temel olarak Covid-19 krizinden çıkışın, ülke ekonomilerinde turizm gelirlerinin katkısı ve Covid-19 krizi ile olan başarıları arasındaki ilişkiye dayalı olduğu anlaşılmaktadır. Buradan hareketle; turizm gelirlerinin genel ekonomi içerisinde daha büyük oranda yer aldığı ülkelerin Covid-19 krizi ile mücadeleleri ne kadar başarılı ise krizi de o kadar 
çabuk atlatmalarının söz konusu olduğu belirtilebilir. Bununla birlikte ilgili pazarların kamuoylarını bilgilendirmek açısından Türkiye'nin çabalarına ve Covid-19 salgınıla ilgili durumu konularına yönelik bilgilendirmelerin yapılması ve potansiyel turistlerin Covid-19 krizi sonrasındaki hayallerinin beslenmesi bağlamında etkili bir turizm iletişiminin geliştirilmesi önerilebilir. Aynı şekilde bu süreçte dijital verilerin değerlendirilmesi ve sosyal medyanın izlenmesinin de önem arz ettiği belirtilebilir. Bu anlamda turist taleplerinin doğru bir şekilde tahmin edilebilmesi için Büyük Veri (Big Data)'nın analiz edilerek turizm trendleri, tüketici eğilimleri, sektörün öncelikleri ve yeni gereklilikler konularında çalışacak bir ekibin oluşturulması elzemdir.

Covid-19 krizi sonrasında turizm sektörü ve ulaşım kodlarında birtakım yeniliklerin geleceğine kesin gözüyle bakılmaktadır. Turizmin etik kodlarıyla birlikte, insanların birbirleriyle, tarihi eserlerle ve çevreyle olan ilişkilerinin de değişime uğrayacağı belirtilebilir. Bu değişimin olumlu yönde ve dayanışma içerisinde gerçekleşmesi beklenmektedir. Buna ek olarak, işletmeler ve ulaşıma yeni hijyen kurallarının geleceği, "Sağlık ve Güvenlik" kurallarının "Hijyen" merkezli değişime uğrayacağı öngörülmektedir. Seyahatin kendi isteklerimize göre sınırsızca kullanacağımız bir "hak" olmaktan çıarak birtakım sorumlulukları taşımaya doğru evirileceği belirtilebilir.

Yine bu süreçte, ülke koşullarına uygun bir yapının oluşturulması gerektiği ve Covid-19 krizinden sonra daha fazla önem kazanmış bir şekilde öne çıkacağı öngörülen "destinasyon" ve "lokalizasyon" kavramlarının turizmde yönetim yaklaşımının merkezine getirilmesi gerektiği belirtilebilir. Bu dönüşümü, geçmiş dönemlerde yaşanan çeşitli krizlerde ağır bedeller ödemiş olan Türkiye'nin Covid-19 krizini "geleceğe dönük" bir şekilde ve "uzun vadeli" çözümüyle neticelendirmesi gerektiği ifade edilebilir.

Covid-19 salgınının sosyal ve ekonomik hayata etkisinin bugüne kadar yaşanan tüm kriz dönemlerinden daha büyük ve kalıcı etkiler bırakacağı söylenebilir. Bu salgın, dünya tarihinde ilk kez ülkelerin sınırlarını kapatmasına, havayollarının faaliyetlerini sonlandırmasına ve seyahatlerin yasaklanmasına yol açmıştır. Covid-19 krizi bu bağlamda ele alındığında, sürecin her aşamasında "yeni" olarak adlandırılabilecek bir olay ve krizle yüz yüze olunduğu bilinmeli ve kriz yönetimi bu doğrultuda planlanmalıdır. Dünya tarihinde yaşanan krizlerin küresel boyutta etkileri olsa da "bölgesel" olarak nitelendirilebilecek krizlerin de olduğu bilinmektedir. Yaşanılan Covid-19 krizinin ise tam olarak küresel olduğu görülmektedir. Bu nedenle bu süreçte kriz yönetiminin küresel olmasının önemli olduğu ifade edilebilir. Dayanışma ve paylaşımın ön planda olması gereken Covid-19 krizine verilen cevapların bölgesel ve küresel ölçekteki iş birlikleriyle gerçekleştirilmesi oldukça önem arz etmektedir.

Son olarak, Covid-19'un yol açacağı zararların henüz tam anlamıla öngörülemediği ancak bu ortamda da atılacak pek çok adımın bulunduğu söylenebilir. Türkiye olarak önceliğin turizm sektörünün ayakta kalmasını sağlayacak havayolları, oteller ve seyahat acentalarına sunulacak "destek kredileri", "seyahatlere ilişkin mevzuat değişiklikleri", "ücretli ve ücretsiz izin uygulamalarında çalışanlara sunulan maddi yardımlar" vb. finansal enstrümanlar geliştirmeleri gerektiği belirtilebilir. Diğer ülkelerde olduğu gibi Türkiye'nin de finansal enstrümanlarını olanakları dâhilinde uygulamaya koyması ve iç turizm akımlarının endüstrinin gelişme dinamiğini oluşturması nedeniyle iç pazara sadece kriz dönemlerinde değil, her zaman gereken önemi vermesi önerilmektedir. 


\section{KAYNAKÇA}

Bağlıkaya, F. (2020). https://www.turizmaktuel.com/haber/turizm-sezonu-mayis-ta-acilir-miiste-tepkiler [Erişim Tarihi: 06.12.2020].

Bahar, O. (2020). https://www.turizmajansi.com/haber/kurtulus-ic-turizm-pazarinda-olabilir-1h37500 [Erişim Tarihi: 07.12.2020].

Balc1, Y. Çetin, ve G. https://www.ticaret.edu.tr/uploads/haberler/1374/\%C4\%B0stihdam\%20Raporu.pdf [Erişim Tarihi: 06.12.2020].

Büyüköztürk, Ş., Çakmak, E. K., Akgün, Ö. E., Karadeniz, Ş. ve Demirel, F. (2017). Bilimsel Araştırma Yöntemleri. Pegem Atıf İndeksi.

Congar, K. (2020). https://tr.euronews.com/2020/04/22/covid-19-turizm-sektorunu-vurdudunyada-en-cok-etkilenen-ulkeler-hangileri-turkiye-kac-nc [Erişim Tarihi: 25.05.2020].

Dünya Sağllk Örgütü (WHO) (2020). https://covid19.who.int [Erişim Tarihi: 06.12.2020].

Dünya Turizm Örgütü (UNWTO) (2020). https://www.unwto.org/sites/default/files/news/untourism-news-11.html [Erişim Tarihi: 01.06.2020].

Dünya Turizm ve Seyahat Konseyi (WTTC) (2020). https://wttc.org [Erişim Tarihi: 01.06.2020].

Erdoğan, H. (1995). Ekonomik Sosyal Kültürel Çevresel Yönleriyle Uluslararası Turizm. Bursa: Uludağ Üniversitesi Yayınları.

Ersoy, M. N. (2020). https://www.haberler.com/kultur-ve-turizm-bakani-ersoy-canli-yayinda13230461-haberi/ [Erişim Tarihi: 20.05.2020].

Ersöz ve Öztürk (2020). https://www.bbc.com/turkce/haberler-turkiye-52445082 [Erişim Tarihi: 01.06.2020].

Gökdeniz, A., Yakup, D., Aşık, N. A., Münger, L. ve Taşkır, H. (2009). Türkiye'de İç Turizm Kavramı ve İç Turizmde Önemli Bir Destinasyon Olan Ayvalık'ta Müşteri Arz ve Talebine Yönelik Ampirik Bir Araştırma Işığında Geliştirme Stratejileri. Balıkesir Üniversitesi Sosyal Bilimler Enstitüsü Dergisi, 12(22), 216-231.

Gursoy, D. and Gavcar, E. (2003). International Leisure Tourists' Involvement Profile. Annals of Tourism Research, 30(4), 906-926.

Guzel, M. T. (2020). http://www.flashhaberlondra.com/yasam/turkiye-saglikli-turizmsertifikasyonu-programini-baslatti-h19073.html [Erişim Tarihi: 07.12.2020].

Güzel, Ö. (2011). Türkiye'de İç Turizm Pazarı Analizi ve Pazarı Canlandırmaya Yönelik Alternatif Turizm Olanakları. Mustafa Kemal Üniversitesi Sosyal Bilimler Enstitüsü Dergisi, 8(16), 127-144.

http://www.turizmyatirimdergisi.com.tr/images/dergi/93-tyd-93_dusuk_compressed.pdf [Erişim Tarihi: 07.12.2020].

Kaduker, O. Ö. (2020). https://www.milliyet.com.tr/gundem/korona-turizmde-neleridegistirecek-6186705 [Erişim Tarihi: 06.12.2020].

Karayal, K. ve Küçükyılmaz, K. (2020). https://turizmdays.com/tr/news/turizmde-canlanma-icpazar-ile-baslayacak-7729.html [Erişim Tarihi: 14.05.2020].

Kilit, T. (2020). https://www.tourismtoday.net/tolga-kilit-2016-daki-gibi-ic-pazar-yine-kurtariciolabilir [Erişim Tarihi: 30.04.2020]. 
Kiros, M., Andualem, H., Kiros, T., Hailemichael, W., Getu, S., Geteneh, A., Alemu, D. and Abegaz, W. E. (2020). COVID-19 Pandemic: Current Knowledge About the Role of Pets and Other Animals in Disease Transmission. Virology Journal, 17(1), 1-8.

Malhotra, N. K. (2004). Marketing Research an Applied Orientation. Pearson Prentice Hall: New Jersey.

OECD (2020). https://read.oecd-ilibrary.org/view/?ref=124_124984- 7uf8nm95se\&title=Covid19_Tourism_Policy_Responses [Erişim Tarihi: 21.05.2020].

Önal, İ. (2020). https://www.turizmgunlugu.com/2020/05/02/irfan-onal-covid-19-turkiyeturizmi/ [Erişim Tarihi: 05.05.2020].

Schwartz, D. A. and Graham, A. L. (2020). Potential Maternal and Infant Outcomes from (Wuhan) Coronavirus 2019-Ncov Infecting Pregnant Women: Lessons from SARS, MERS, and Other Human Coronavirus Infections, Viruses, 12(2), 2-16.

SOCEMIE (2020). https://tr.euronews.com/2020/05/13/koronavirus-yasaklar-gevsetilirkenuluslararasi-seyahatlerin-gelecegi-ne-olacak-thy-ucus [Erişim Tarihi: 07.12.2020].

Şahin, S. K. (2020). https://www.sdplatform.com/Dergi/1377/COVID-19-ve-degisimfirtinasi.aspx [Erişim Tarihi: 07.12.2020].

Şimşek, A. (2012). Evren ve Örneklem, (Editör) Şimşek, A.: Sosyal Bilimlerde Araştırma Yöntemleri içinde. Eskişehir.

Tanrıverdi, H. ve Oktay, K. (2002). Turizmde Tüketici Sorunları ve Tüketici Haklarının Korunması Üzerine Bir Araştırma, Yönetim ve Ekonomi: Celal Bayar Üniversitesi İktisadi ve İdari Bilimler Fakültesi Dergisi, 9(1), 123-134.

Turizm Bakanlığı (2017). 3. Turizm Şurası Tam Zamanı Şura Kitabı. Ankara: Turizm Bakanlığı Özel Matbaası.

Türkiye Otelciler Birliği (TÜROB) (2020). http://www.turob.com/tr/haberler/str-mart-2020raporu-dunya-turizmine-buyuk-fatura [Erişim Tarihi: 07.06.2020].

Türkiye Turizm Tanıtım ve Geliştirme Ajansı (2020). https://www.tga.gov.tr/turkiyenin-guvenliturizm-programi-hakkinda/ [Erişim Tarihi: 17.06.2020].

Wu, P., Hao, X., Lau, E. H., Wong, J. Y., Leung, K. S., Wu, J. T., Cowling, B. and Leung, G. M. (2020). Real-time Tentative Assessment of the Epidemiological Characteristics of Novel Coronavirus Infections in Wuhan, China, as at 22 January 2020. Eurosurveillance, 25(3), 1-6.

Yavuz, R. (2020). https://www.turizmgunlugu.com/2020/05/08/ulkelerin-turizmde-aldigicorona-onlemleri/ [Erişim Tarihi: 19.05.2020]. 